\title{
Energia ulicy
}

\section{Energy of the street}

Wystawa transparentów ze Strajku Kobiet.

Barak Kultury, Poznań, 23 listopada - 07 grudnia 2020

/ The banner exhibition from the Women's Strike.

Barak Kultury, Poznań, November 23 - December 72020.

DOI: 10.12775/LL.3.2021.009| CC BY-ND 4.0

\section{Krótki żywot transparentu}

Powstaje w myśli. Czasami pod wpływem silnej emocji, czasami za sprawą zewnętrznej inspiracji czy aktu kreatywności. Materializuje się na kartonie, zazwyczaj w czerni lub czerwieni, flamastrem, pędzlem, palcem. A później zabierany jest na ulice. Tam wymachuje się nim lub po prostu trzyma wysoko — tak, by wszyscy widzieli. A najlepiej, by czuli to, co autor ma do przekazania. Po kilku godzinach wraca się z nim do domu albo porzuca gdzieś przy krawężniku. W niektórych wypadkach jednak zabiera się go na Aleje Marcinkowskiego w Poznaniu pod numer 21, gdzie wiesza się go za szybą. I tak oto w witrynie okiennej Baraku Kultury transparent nabiera nowego znaczenia. Ale jakiego?

\section{To nie sa zwykłe dzieła sztuki}

„Energia protestów nam się udzielała, czuliśmy ją pod oknami”, stwierdził podczas naszej rozmowy Przemek Prasnowski, prezes fundacji Barak Kultury, i dodał:

I Słowa Przemka Prasnowskiego z wywiadu przeprowadzonego przeze mnie 15 stycznia 2021. 
„Najpierw wywiesiliśmy hasło, żeby było jasne, po której stronie jesteśmy”. Później członkowie fundacji wpadli na pomysł pozbierania porzuconych transparentów z ulicy (niektóre z nich leżały zamokłe w kontenerze przed budynkiem Baraku). Chcieli je jakoś uwiecznić, zapamiętać, pokazać to, co się dzieje na ulicy, jaka jest rzeczywistość. „Czytanie rzeczywistości - jak mówi Prasnowski - należy do obowiązków instytucji kultury”, a Barak od kilkunastu lat jest właśnie taką instytucją. Podejmowane w nim inicjatywy dotyczą m.in. tematów dyskryminacji i wykluczenia, wsparcie Strajku Kobiet było więc w tym przypadku oczywistością.

Seria protestów związanych z Ogólnopolskim Strajkiem Kobiet rozpoczęła się 22 października 2020 r. Była natychmiastową reakcją na wydanie przez Trybunał Konstytucyjny orzeczenia, będącego próbą zaostrzenia ustawy antyaborcyjnej. Przez ulice miast i miasteczek w całej Polsce przetoczyły się liczne demonstracje, a ich skala przewyższyła protesty dotyczące dostępu do legalnej aborcji odbywające się w poprzednich latach. Uczestniczki i uczestnicy postulowali nie tylko możliwość wykonywania w Polsce bezpiecznej aborcji, ale także m.in. dymisje rządu oraz rozdział państwa od Kościoła. Strajk objął swoim zasięgiem obywatelki i obywateli całego kraju, bez względu na wiek czy grupe społeczną. Wszystkich łączył wspólny cel.
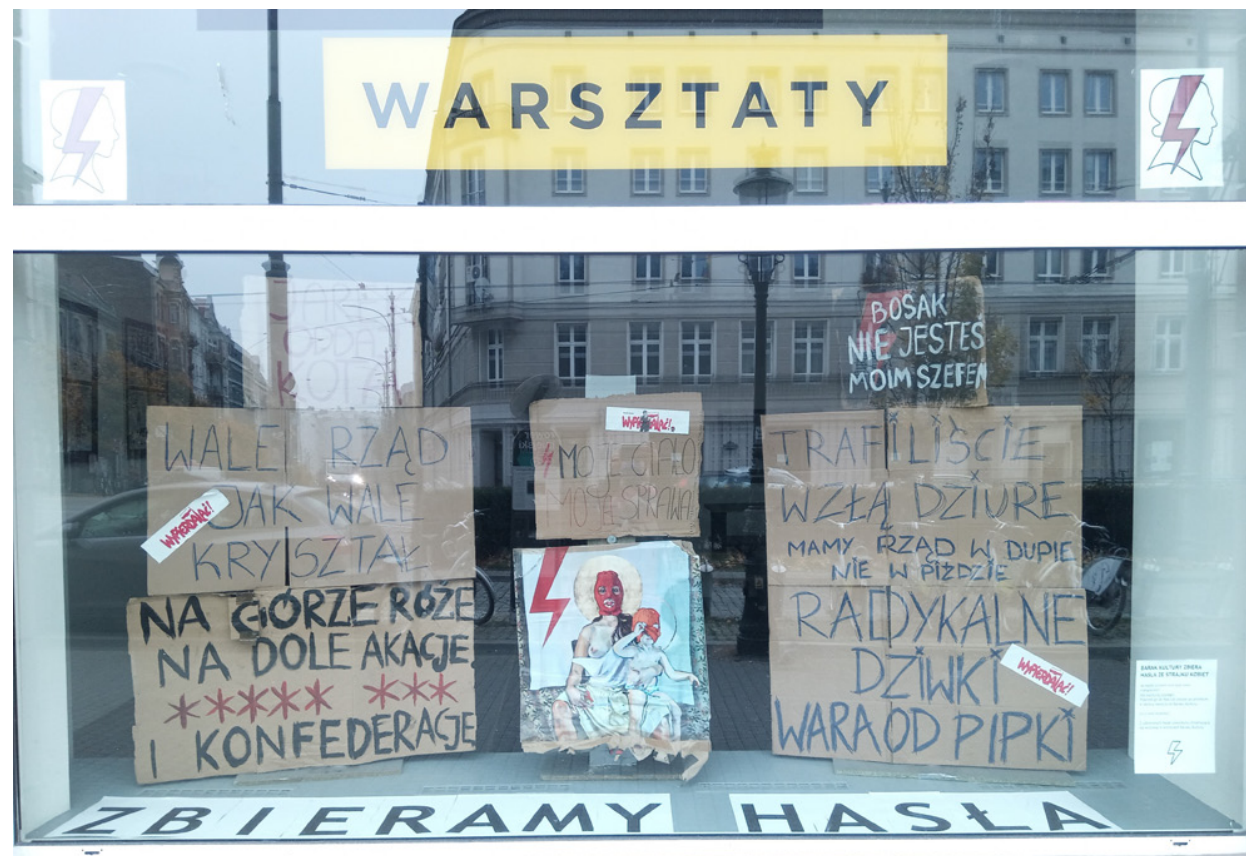

Il. 1 Okno siedziby fundacji Barak Kultury z wystawą transparentów ze Strajku Kobiet. Fot. Barak Kultury. 
Galeria w Baraku Kultury miała podtrzymać energię ulicy, dlatego też za jej miejsce wybrano witrynę okienną - widoczną dla przechodniów, oddającą atmosferę życia publicznego. Od 23 listopada 2020 r. każdy mógł przynieść do Baraku swój transparent i tym samym przyczynić się do tworzenia wystawy, którą zaplanowano na dwa tygodnie, ale ostatecznie została wydłużona o kilka dni. Miała ona charakter dynamiczny, to znaczy zmieniała się wraz z przynoszonymi w kolejnych dniach eksponatami. Przez kilka tygodni osoby spacerujące w okolicach fundacji mogły przeczytać w jej oknach takie hasła jak: „Na dole róże, na górze akacje, ******** i konfederacje”, „Moje ciało, moja sprawa”, „My się nie chcemy bić, my się chcemy całować” czy „Trafiliście w złą dziurę, mamy rząd w dupie, nie w piździe”.

Reakcje na te nietypowe dzieła sztuki były różne. Przeważnie ludzie odnosili się do nich pozytywnie, jednak zdarzały się też osoby oburzone wulgarną treścią haseł prezentowanych $\mathrm{w}$ witrynie publicznej instytucji. Zosia z Baraku Kultury $-\mathrm{z}$ którą rozmawiałam podczas wizyty w siedzibie fundacji - skomentowała odbiór galerii stwierdzeniem, że wywoływanie dyskusji wokół ważnych tematów społecznych jest jednym z zadań ośrodków kultury. Wystawa banerów z pewnością prowokowała do zastanowienia się nad własną opinią na temat sytuacji politycznej w kraju, a może nawet do zmiany tej opinii. Przemek Prasnowski dodał, że hasła z transparentów żyją, ponieważ są używane do komentowania współczesnych wydarzeń, a październikowe strajki nazwał przełomem, jeśli chodzi o stosowane w Polsce formy komunikacji. W wypowiedzi dla „Gazety Wyborczej” stwierdził on ponadto, że nastąpiło zerwanie z językowym tabu (Przybylska 2020). Ludzie zaczęli jednoznacznie określać, czego oczekują, przełamali wszelkie społeczno-językowe bariery, co słychać i widać podczas manifestacji. Istotne wydaje się również to, że przewrotu tego dokonały kobiety, którym - zgodnie z kulturowym standardem - rzadziej niż płci przeciwnej przyznaje się prawo do używania wulgaryzmów. Tym samym intymna strona kobiet, z którą mamy problem w publicznym dyskursie, została odczarowana.

Na wystawie nie zabrakło również haseł dowcipnych, obnażających absurdy polityki, które - jak ujął to jeden z organizatorów - nawiązywały do wolnościowego karnawału, np. „Jarek oddaj kota” czy „Leć na księżyc, po coś go skradłeś”. Takie hasła wymyślają ludzie, którzy według słów Marcina Wichy „już nie maja siły się bać" (2020: 2).

$\mathrm{Na}$ jednym z transparentów obok błyskawicy, symbolu protestów, pojawiła się też Matka Boska z dzieciątkiem - oboje w czerwonych kominiarkach. Wywołało to skrajne reakcje, dla niektórych odbiorców było bowiem formą obrazy uczuć religijnych. Wizerunek ten jest jednak charakterystycznym przykładem sprzeciwu wobec niektórych działań Kościoła Katolickiego, co stanowiło jeden z ważnych elementów Strajku Kobiet. W tym kontekście można stwierdzić, że wystawa w Baraku była pozbawiona cenzury. Choć na niektóre wulgaryzmy naklejono kartki z ośmioma gwiazdkami $(* * * * * * * *)^{2}$, to zabieg ten służył nie

2 Gwiazdki oznaczają osiem liter składających się na frazę, ,jebać PIS”, często używaną w czasie opisywanych protestów. 
tyle eliminowaniu określonych treści, co raczej ich wzmacnianiu i uogólnianiu poprzez zastosowanie powszechnie zrozumiałego kodu symbolicznego.

Transparenty zdjęto z witryny w pierwszej połowie grudnia $2020 \mathrm{r}$. Barak Kultury przechowuje je w swoich magazynach i zbiera kolejne, planując następne odsłony wystawy.

\section{Dynamika rzeczy}

Wróćmy na moment kwestii zasygnalizowanej na wstępie. Opisuję w nim etapy życia transparentu, od chwili jego powstania, do czasu znalezienia się na wystawie. Zazwyczaj życie to kończy się wcześniej, a rola transparentu ogranicza się do towarzyszenia jego twórcy podczas manifestacji. Można zatem stwierdzić, że pracownicy Baraku dzięki tej wystawie przedłużyli transparentom życie, a co za tym idzie, przedłużyli również okres oddziaływania ich treści, nadając im zarazem nową funkcję.

Jak zauważa Ewa Domańska (2008: 14), „w biograficznym podejściu rzeczy mają materialną tożsamość (material identity), a czasami mają wiele tożsamości, które zmieniają się w czasie i wraz ze zmianą kontekstu; mają swoje życie, które zaczyna się od punktu a, a kończy na b; w tym życiu coś im się przydarza”. Autorka nawiązuje tu do koncepcji nowej kultury materialnej, w której na rzeczy nie patrzy się już jak na stałe i posiadające niezmienne właściwości obiekty. Rzecz może zmieniać swoje tożsamości, wędrując w czasie i przestrzeni. Tomasz Rakowski pisze z kolei, że to właśnie trajektorie rzeczy - ścieżki, jakie obierają - dają „punkt do uchwytu rozgrywających się procesów kulturowych” (Rakowski 2008: 57). Przekaz, który zawiera transparent zazwyczaj jest ulotny, podobnie zresztą jak sam jego nośnik, robiony na ogół z nietrwałych materiałów, na jedną lub kilka okazji w odpowiedzi na bieżącą sytuację polityczno-ekonomiczną (lub inną). Mimo swej materialności, jest efemeryczny, a uczynienie z niego części wystawy odbiera mu nieco z tej ulotności. Uliczna energia, którą niesie jego treść, zamknięta za szybą, jest namacalną pozostałością po społecznym zrywie. Transparent zrobiony z recyklingowanej papierowej pulpy nie rozmoczył się na deszczu, co w pewien sposób zmieniło trajektorię jego egzystencji. Swoiste rozdroże, na którym karton został ocalony, jest właśnie tym punktem, w którym możemy obserwować rozgrywanie się procesów kulturowych. Sama wystawa pozostaje symbolem tego rozdroża. Wraz z uratowanym kartonem przetrwały zawarte w nim znaczenia, nie tylko napis, ale również emocje, napięcia i gniew społeczny. Wystawa sama w sobie staje się więc kontynuacją sprawczej aktywności uczestników protestów, którzy wpływali nie tylko na działania rządu, ale i na postawy całego społeczeństwa. Karton stał się pewnego rodzaju bronią słabych (Scott 1985), stojących naprzeciw policyjnych pałek i władzy działającej w poczuciu bezkarności.

Barak Kultury przyczynił się zatem do utrwalenia i wzmocnienia wydźwięku haseł w rodzaju „Wypierdalaj” czy „Jesteśmy wkurwione”. Użył do tego własnej przestrzeni (siedziby fundacji), która jednak ma charakter publiczny, bo jest widoczna $\mathrm{z}$ ulicy. W odniesieniu do miejsc, gdzie odbywały się manifestacje 


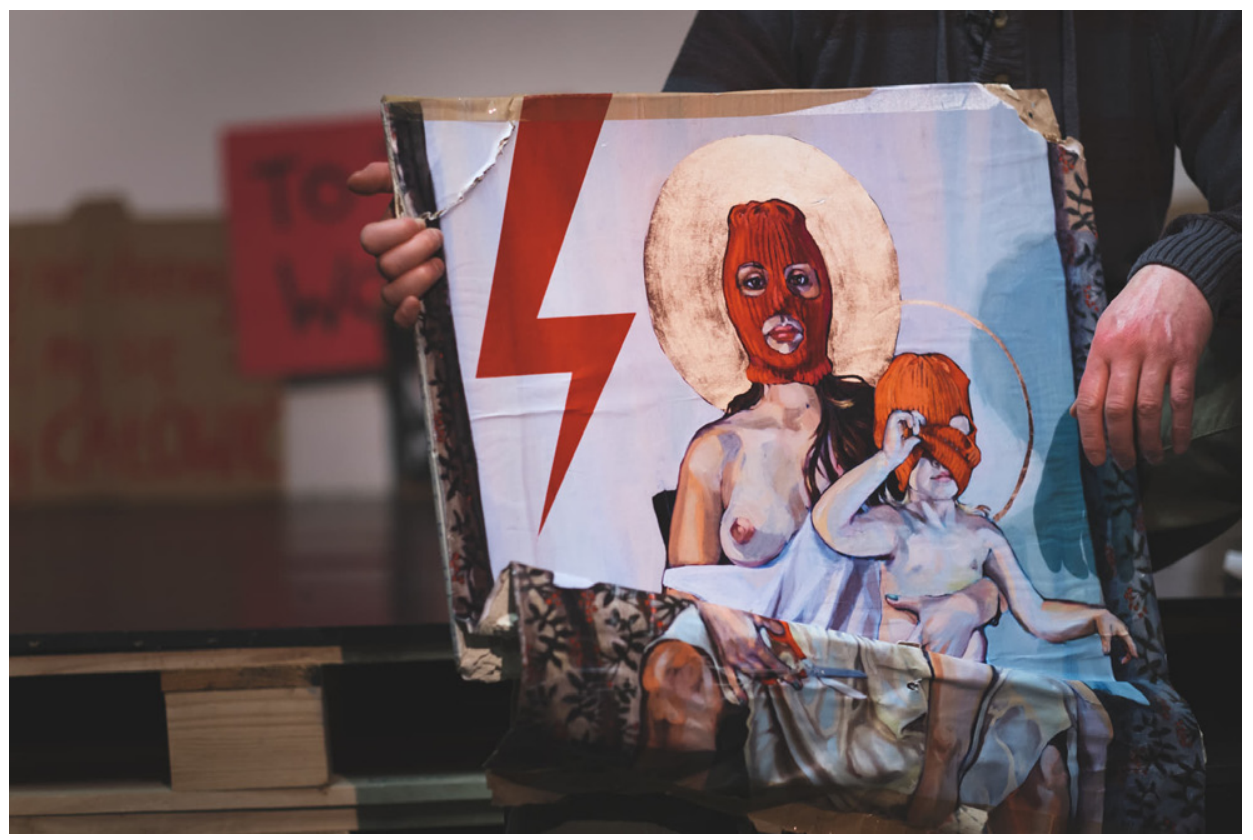

Il. 2 Transparent ze Strajku Kobiet prezentowany na wystawie fundacji Barak Kultury. Fot. Barak Kultury.

Czarnych Protestów z 2017 r. napisano, iż „wybór tej przestrzeni to gest sam w sobie - znak, że chodzi o sprawy publiczne, dotyczące całej lokalnej społeczności” (Rancew-Sikora, Steciąg 2017: 34). Analogicznie jest w przypadku Baraku, który jako instytucja kultury oddaje swoją przestrzeń ludziom, by mogli powiedzieć to, co mają do powiedzenia. Witryna okienna staje się więc swego rodzaju wycinkiem Placu Wolności w sobote 31 października o 20:oo lub fragmentem ulicy Św. Marcina w czwartek 19 listopada o 19:00, a znajdujące się w niej eksponaty są manifestacją, aktem obywatelskiego sprzeciwu.

Mamy zatem zbiór kartonów z hasłami i witrynę okienną - dwóch aktorów, tworzących pare pozornie statyczną. W rzeczywistości to jednak aktorzy w ruchu, którzy swą wizualnością niosą dźwięk skandującego tłumu, świadcząc o historycznym momencie, o społecznym zrywie, wspólnotowości, sile kobiecego „wkurwu”, energii ulicy, która wciąż jest i wciąż mówi: „Mamy dość!”. Wystawa transparentów oddaje tym samym swoistą dynamikę procesów społecznych, która - jak pisał Tomasz Rakowski - „toczy się [...] także w sferze rzeczy” (2008: 56).

Długo zastanawiałam się, pod jakim kątem przeanalizować inicjatywę Baraku Kultury oraz jej relację do samych protestów. W zależności od przyjętej perspektywy mogłabym skupić się na różnych aspektach: zachowaniu dziedzictwa kulturowego, tworzeniu/dokumentowaniu specyficznych form folkloru politycznego, współtworzeniu tożsamości indywidualnej i zbiorowej, werbalnym 


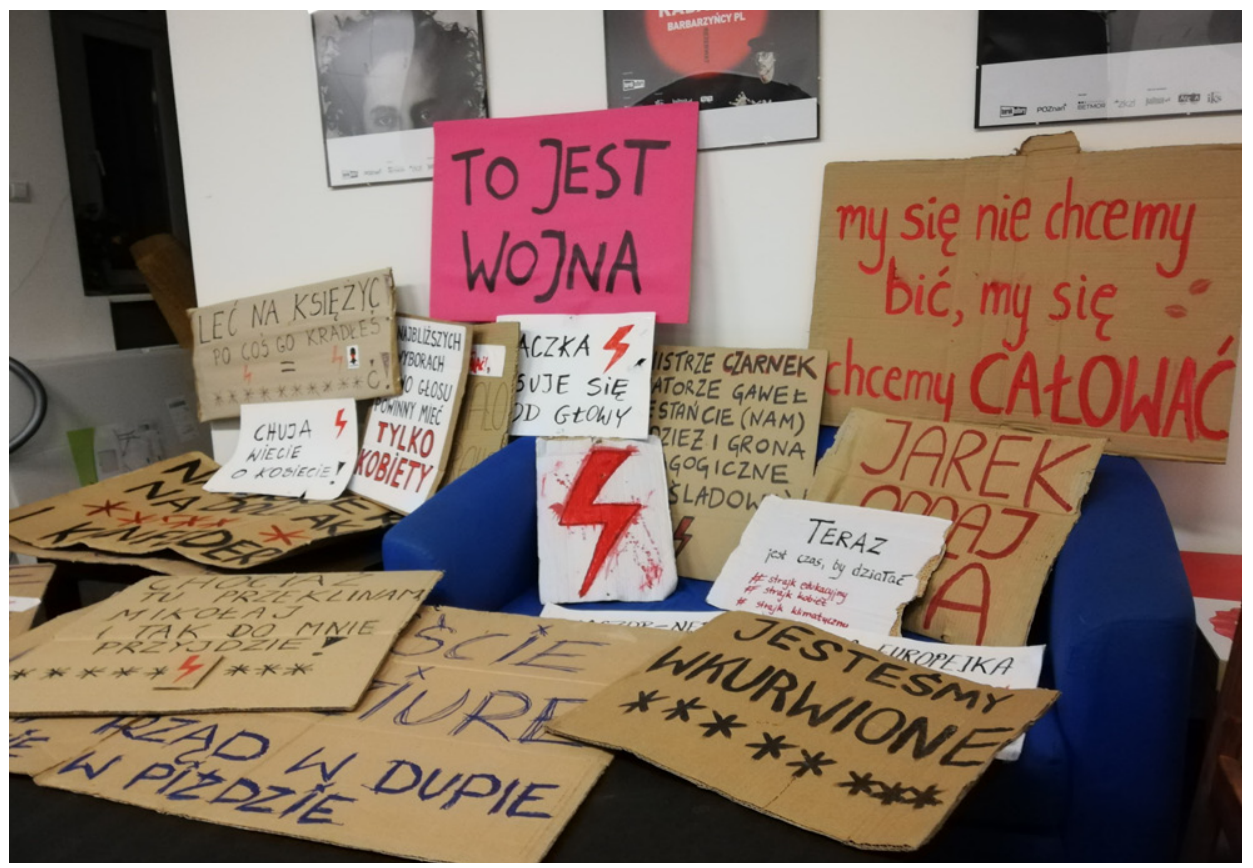

Il. 3. Kolekcja transparentów ze Strajku Kobiet zgromadzona na zapleczu siedziby fundacji Barak Kultury. Fot. Urszula Małecka.

przekazie haseł, wreszcie ukrytym rozwarstwieniu oraz innych społecznych wyzwaniach, jakie ujawniają się w tej sytuacji. Wystawa dotyka wszystkich tych kwestii, co już samo w sobie świadczy o tym, że jej stworzenie należało do pomysłów udanych. Zdecydowałam się ując ją w perspektywie zwrotu ku rzeczom (Domańska 2008: 12), gdyż uznałam, że ta perspektywa najlepiej pozwoli mi uwydatnić problem poruszony przez jej autorów. Głównym celem tego projektu było bowiem uchwycenie nieuchwytności. Zrobiono to za pomocą obrazu, co okazało się idealnym rozwiązaniem, ponieważ żyjemy obecnie w kulturze mocno zikonizowanej (Drozdowski 2017: 22). Galeria przyciaggnęła szerokie grono odbiorców, wywołała niejedną dyskusję, być może zasiała ziarno wątpliwości, w umysłach tych, którzy swe poglądy już dawno zdążyli ugruntować. Tego ostatniego nie wiemy, możemy mieć tylko nadzieję, że tak się stało. A nadzieja - także ona - bije z tych pomazanych farbą kartonów, bo przecież jak zauważa Przemek Prasnowski - „za każdym takim hasłem na kartonie stoi konkretny człowiek i jego komunikat" (Przybylska 2020). Wystawa transparentów w Baraku Kultury pozwoliła lepiej wybrzmieć takim komunikatom. Mimo że w ostatnich miesiącach były one słyszalne zarówno w Polsce, jak i na świecie, istnieje potrzeba zwiększenia siły ich głosu. Ich utrwalanie wydaje się przy tym moralnie i poznawczo konieczne, gdyż są one ulotnym świadectwem narodzin nowego ruchu społecznego, a może nawet gruntownej przemiany wartości w naszym społeczeństwie. 


\section{BIBLIOGRAFIA}

Domańska, E. (2008). Humanistyka nie-antropocentryczna a studia nad rzeczami. Kultura Wspótczesna, 57(3), 9-21.

Drozdowski, R. (2017). Jak i po co badać wizualność protestów społecznych?. Czas Kultury, 33(4), 21-26.

Przybylska, A. (2020, 5 listopada). Barak Kultury zbiera kartony z protestów strajku kobiet [artykuł na portalu Wyborcza.pl]. Pobrano z : https://poznan.wyborcza.pl/poznan /7,36001,26477999, barak-kultury-zbiera-kartony-z-protestow-strajku-kobiet-za.html?fbclid=Iw ARoEyujWroRft2QbgBirSQgm4Vq3BzTt5xA9j3k9utYyeLJHUTrATfjHVKQ

Rakowski, T. (2008). Przemiany, przesunięcia, przedmioty przejściowe. Antropologia rzeczy. Kultura Współczesna, 57(3), 55-72.

Rancew-Sikora, D., Steciąg, M. (2017). „Niech się bawią”? O związkach radykalności z karnawałem na demonstracjach publicznych kobiet. Czas Kultury, 33(4), 27-34.

Scott, J. C. (1985). Weapons of the weak: Everyday forms of peasant resistance. New Haven: Yale University Press.

Wicha, M. (2020). Życzenia. Pismo. Magazyn Opinii, 36(12). Pobrano z: https://magazynpismo.pl/ idee/felietony/zyczenia-marcin-wicha/?seo=pw\# 